\title{
VLIV COVID-19 NA VÝBĚR EKONOMICKY OPTIMÁLNÍ VARIANTY LETOUNU
}

\section{THE INFLUENCE OF COVID-19 ON THE CHOICE OF ECONOMICALLY OPTIMAL VARIANT OF THE AEROPLANE}

Patrik Matzke1,*

Abstrakt Tento príspěvek popisuje proces výběru optimální varianty letounu, a jeho změny v důsledku současné koronakrize, která celosvětově poznamenala leteckou dopravu. Zahrnuje metodické postupy, způsoby pořízení letadel, případně charakteristiku jednotlivých variant a kritérií ovlivňujících výběr. Zároveň se tento příspěvek snaží poukázat na preference nově př́chozích letounů v rámci flotil leteckých dopravců, které bývají v důsledku této krize mnohdy omezeny a mnoho kritérií a aspektů, jenž by za normálních okolností hrály velkou roli, jsou upozaděny.

Klíčová slova Letiště, Koronavirus, Aerolinie, Osobní letecká doprava

Summary This article describes the process of selecting the optimal variant of the airplane and its changes because of the current corona crisis, which has been marked by air traffic worldwide. It shall include methodological procedures, methods of acquisition of aircraft and, where appropriate, the characteristics of individual variants and criteria affecting the selection. At the same time, this contribution seeks to point to the preferences of the new arrivals under the air carriers 'fleets, which are often the result of this crisis.

Keywords $\quad$ Airports, Coronavirus, Airlines, Passenger Air Transport

1 Vysoká škola báňská - Technická univerzita Ostrava, 17. listopadu 2172/15, 708 00, Ostrava.

* korespondenční autor, tel.: +420 596995 500, e-mail: patrik.matzke.st@vsb.cz 


\section{1 ÚVOD}

Odvětví letecké dopravy, které celosvětově velmi významně přispívalo k rozšiřrení a oblíbenosti nových destinací a turistických cílů, v současné době čelí největší krizi za svou staletou historii. Od počátků této krize panuje obrovská nedůvěra k cestování na větší vzdálenosti, a letecká doprava jako taková ztratila většinovou část svých typických zákazníků především $\mathrm{z}$ důvodu strachu $\mathrm{z}$ nákazy v letecké infrastruktuře, kde často dochází ke kontaktu mnoha různých lidí ze všech konců světa. A v rámci krátkého časového intervalu tak představuje ideální nástroj pro šíření nevyzpytatelného viru mezi jeho účastníky.

Vzhledem k tomu, že současná situace v letecké dopravě je velmi ojedinělá, je prakticky nemožné hodnotit ji a porovnávat s jinými problémy, které zasáhly leteckou dopravu v minulosti. Letečtí dopravci a provozovatelé letounů měli prakticky velmi krátký interval na to, aby se rozhodli, jak budou dále pokračovat. Žádná krize doposud na letecký svět neměla takový vliv, jako tomu bylo $\mathrm{v}$ prvním kvartálu loňského roku s příchodem koronaviru. Provoz letecké dopravy byl rázem snížen o $80 \%$. (ČNB, 2021)

Velká část leteckých dopravců bylo nuceno své flotily takzvaně zmrazit, což v letecké interpretaci znamená úplné uzemnění letounů, pozastavení jejich leasingů, a zakonzervování pro další použití. jižv březnu roku 2020 se na základě prognóz a predikcí některé aerolinie rozhodly pro uzemnění většiny svých letounů, což je prakticky odsoudilo ke rapidnímu snižování nákladů, kde docházelo k opravdu masivnímu propouštění provozních, servisních ale i organizačních složek. Prodeje movitého i nemovitéhomajetku a prakticky tato situace stále pokračuje. Bohužel z pohledu výkazu zisku a ztráty bývá pořád největší položkou v rámci nákladů právě plat leteckého personálu čili zaměstnanců. Mnoho kvalifikovaných pilotů, servisních techniků, plánovačů a dalších zaměstnanců v letecké dopravě přišlo o práci, nebo jsou na částečně dotovaném úvazku. V současné chvíli není vůbec výjimkou, když potkáte pilota s dlouholetou praxí na volné noze. Nutno však říci, že zavedení těchto opatření letecké společnosti zajistilo alespoň minimální šanci pro opětovné navrácení do provozu.

K mírnému zlepšení situace došlo dle předpokladů přes letní sezónu, kdy obvykle dochází ke zvýšení poptávky a častějším rotacím tzv. charterových letů, tudíž piloti a technici byli povoláni zpět do služby, nicméně s koncem letní sezóny lze očekávat následné snížení poptávky, a ubývání leteckých spojení. Bohužel je to dáno rapidním snížením zájmu o leteckou dopravu, a především také vlnou omezení jednotlivých států, které často velmi tvrdě vystupují proti turistickému ruchu a zavádí všemožná opatření, tak aby zajistily bezpečnost a omezily šíření Covid-19. (MZČR, 2021) 


\section{VÝBĚR EKONOMICKY OPTIMÁLNÍ VARIANTY POŘÍZENÍ LETOUNU}

V rámci výběru ekonomicky optimální varianty pořízení letounu je třeba zohlednit mnoho aspektů. Aerolinie při výběru letounů do flotily zpravidla čelí velkému stresu, jelikož mají samozřejmě velkou odpovědnost, a výběr optimální varianty může často ovlivnit konkurenceschopnost firmy na delší časové období dopředu.

Velmi důležitým tématem při nasazování a zavádění nových typů letounů do provozu je stanovení metodiky výběru vhodných typů letounů, respektive variant, které budou splňovat mnohdy četné požadavky leteckých dopravců či provozovatelů aerolinií a najít tak nejvhodnější metodu, která bude mít při všech vstupujících faktorech, prokazatelně optimální výstup ve formě varianty letounu. Vstupujícími faktory se u těchto metod rozumí veškerá kritéria, jako například cestovní rychlost, pořizovací cena nebo přepravní kapacita. Tyto faktory do výběru vstupují s určitou preferencí, jež byla předem stanovena, např́íklad některými z metod stanovení vah kritérií. Tyto váhy se pak následně zohlední, a v rámci výběru pak ovlivní výsledky v návaznosti na parametry jednotlivých variant. Jako výhodné se pro tento typ výběrujeví některé z mnoha metod multikriteriální analýzy. (Novák et al., 2010)

Metody multikriteriální analýzy jsou ve své podstatě založeny na matematickém modelování, kde pomocí jednotlivých úloh dochází $\mathrm{k}$ výběru varianty z výčtu realizovatelných variant, na základě všech předem definovaných kritérií.

Mezi realizovatelné varianty se zpravidla řadí takové, které alespoň rámcově splňují požadavky danéholeteckého dopravce či provozovatele a mohou být tudíž zařazeny do výběru. Na tuto prvotní selekci má zpravidla největší vliv subjektivní faktor zadavatele, v tomto prrípadě např́klad aerolinie, která může být ovlivněna spoustou vnějších faktorů, at' už se jedná o finanční důvody, preference konkrétního výrobce, oblíbenost daného typu, marketing, nebo např́íklad obchodní strategie uvádění nových typů letounů. (Fiala et al., 1994)

\section{METODIKA VÝBĚRU - MCA}

Multikriteriální analýza z anglického slovního spojení Multi-Criteria Analysis, je soubor metod, kterými při zohlednění více množství kritérií dokážeme ze souboru realizovatelných variant stanovit tu nejvhodnější. Multikriteriální analýza, resp. rozhodování je kategorizováno jako diskrétní a můžeme na ně pro účely výpočtu nazírat jako na modely. Tyto modely rozhodování jsou popsány množinou variant, množinou hodnotících kritérií a řadou vazeb mezi kritérii a variantami. Zadaná kritéria mohou mít kvantitativní i kvalitativní charakter, mohou být maximalizační i minimalizační a mohou být i navzájem konfliktní. Rozhodovatel nebo skupina rozhodovatelů zadává základní informace o variantách a kritériích, které umožní formulovat vícekriteriální model.

Prvním krokem je stanovení vah kritérií. Získat od rozhodovatele př́mo hodnoty vah je velmi obtížné, avšak existují metody, které na základě jednodušších subjektivních informací od rozhodovatele konstruují odhady vah. Metoda pořadí vyžaduje pouze ordinální informaci, stanovení pořadí kritérií podle důležitosti. Uspořádaným kritériím jsou přiřazena čísla. Nejdůležitějšímu kritériu je přiřazeno číslo $k$, druhému nejdůležitějšímu $k$-1 až nejméně důležitému kritériu číslo 1. Mezi metody stanovení vah kritérií patří například metoda bodovací stupnice, metoda alokace 100 bodů, nebo Saatyho metoda.

Dalším krokem je poté výběr vhodných metod pro stanovení pořadí jednotlivých kritérií, do těchto výpočtů již vstupuje ohodnocení kritérií pomocí vah z předchozího kroku. Mezi tyto metody patří Lineární dílčí funkce užitku, Metoda váženého součtu, Metoda AHP, Metoda TOPSIS a mnoho dalších. V závislosti na charakteristice posuzované problematiky je vybrána jedna nebo více metod k stanovení pořadí variant a potažmo k výběru nejvhodnější varianty. (Novák et al., 2020) 
V první části multikriteriálního rozhodování budou zohledněny 4 vybrané letouny za vstupu dostupných kritérií, tak aby bylo možné prezentovat pořadí v rámci těchto variant. Tyto letouny jsou označeny jako a1, a2, a3, a4. Tudíž množina rozhodovacích variant bude $A=(a 1, a 2, a 3, a 4)$.

Tab. 1: Varianty

\begin{tabular}{|l|l|}
\hline $\mathbf{a}_{\mathbf{1}}$ & Airbus A220-100 \\
\hline $\mathbf{a}_{\mathbf{2}}$ & Airbus A220-300 \\
\hline $\mathbf{a}_{\mathbf{3}}$ & Boeing B737 MAX 7 \\
\hline $\mathbf{a}_{\mathbf{4}}$ & Boeing B737 MAX 8 \\
\hline
\end{tabular}

Množina rozhodovacích variant bude následně hodnocena dle množiny kritérií $\mathrm{K}=(\mathrm{k} 1, \mathrm{k} 2, \mathrm{k} 3, \mathrm{k} 4, \mathrm{k} 5, \mathrm{k} 6, \mathrm{k} 7, \mathrm{k} 8, \mathrm{k} 9, \mathrm{k} 10)$.

Tab. 2: Kritéria

\begin{tabular}{|c|l|}
\hline $\mathbf{k}_{\mathbf{1}}$ & MTOW $[\mathrm{kg}]$ \\
\hline $\mathbf{k}_{\mathbf{2}}$ & Cestovní rychlost $[\mathrm{km} / \mathrm{h}]$ \\
\hline $\mathbf{k}_{\mathbf{3}}$ & Kapacita pasažérů [os] \\
\hline $\mathbf{k}_{\mathbf{4}}$ & Kapacita paliva [L] \\
\hline $\mathbf{k}_{\mathbf{5}}$ & Spotřeba paliva $[\mathrm{kg} / \mathrm{km}]$ \\
\hline $\mathbf{k}_{\mathbf{6}}$ & Spotřeba paliva na sedadlo $[\mathrm{kg} / 100 \mathrm{~km} / \mathrm{seat}]$ \\
\hline $\mathbf{k}_{\mathbf{7}}$ & Dolet $[\mathrm{km}]$ \\
\hline $\mathbf{k}_{\mathbf{8}}$ & Dostup [m] \\
\hline $\mathbf{k}_{\mathbf{9}}$ & Payload $[\mathrm{kg}]$ \\
\hline $\mathbf{k}_{\mathbf{1 0}}$ & Pořizovací cena [USD] \\
\hline
\end{tabular}

Pro lepší orientaci byly varianty a kritéria uspořádány do tzv. kriteriální matice. Tato matice má konečný počet prvků a zobrazuje hodnoty kritérií, respektive provozní charakteristiky jednotlivých variant.

Tab. 3: Kriteriální matice

\begin{tabular}{|c|c|c|c|c|c|c|c|c|c|c|}
\hline \multicolumn{10}{|c|}{ Provozní charakteristiky } \\
\hline Letoun & $\mathbf{k}_{\mathbf{1}}$ & $\mathbf{k}_{\mathbf{2}}$ & $\mathbf{k}_{\mathbf{3}}$ & $\mathbf{k}_{\mathbf{4}}$ & $\mathbf{k}_{\mathbf{5}}$ & $\mathbf{k}_{\mathbf{6}}$ & $\mathbf{k}_{\mathbf{7}}$ & $\mathbf{k}_{\mathbf{8}}$ & $\mathbf{k}_{\mathbf{9}}$ & $\mathbf{k}_{\mathbf{1 0}}$ \\
\hline A220 - 100 & 63100 & 829 & 135 & 21805 & 2,28 & 1,69 & 6297 & 12497 & 15100 & 81000000 \\
\hline A220 - 300 & 69900 & 829 & 160 & 21805 & 2,56 & 1,60 & 6204 & 12497 & 18700 & 91500000 \\
\hline B737 MAX 7 & 80300 & 839 & 172 & 26816 & 2,85 & 1,66 & 7130 & 12000 & 20900 & 99700000 \\
\hline B737 MAX 8 & 82200 & 839 & 210 & 25816 & 3,04 & 1,45 & 6570 & 12000 & 20900 & 121600000 \\
\hline
\end{tabular}


V první části rozhodování je nutné stanovit váhy kritérií. (1) Jinými slovy učinit zjištění předpokládaných dopadů a účinků jednotlivých variant $\mathrm{z}$ hlediska kritérií hodnocení. Pro názornost je v následujícím kroku použita Metoda bodovací stupnice, jako zástupce metod přímého stanovení vah kritérií.

V prvním kroku nastává přiřazení určitého počtu bodů ze zvolené stupnice každému kritériu v souladu s tím, jak posuzovatel hodnotí význam každého kritéria (čím považuje rozhodovatel kritérium za významnější, tím větší počet bodů mu přiřadí). (Fiala et al., 1994)

Výpočet normované váhy kritéria:

$$
v_{i}=\frac{k_{i}}{\sum_{i=1}^{n} k_{i}}
$$

Tab. 4: Stanovení vah kritérií

\begin{tabular}{|c|c|c|c|c|c|c|c|c|c|c|c|}
\hline Kritérium & $\mathbf{k}_{\mathbf{1}}$ & $\mathbf{k}_{\mathbf{2}}$ & $\mathbf{k}_{\mathbf{3}}$ & $\mathbf{k}_{\mathbf{4}}$ & $\mathbf{k}_{\mathbf{5}}$ & $\mathbf{k}_{\mathbf{6}}$ & $\mathbf{k}_{\mathbf{7}}$ & $\mathbf{k}_{\mathbf{8}}$ & $\mathbf{k}_{\mathbf{9}}$ & $\mathbf{k}_{\mathbf{1 0}}$ & $\boldsymbol{\Sigma}$ \\
\hline Počet bodů & 3 & 1 & 10 & 2 & 3 & 6 & 4 & 1 & 5 & 10 & 45 \\
\hline Normovaná váha & 0,07 & 0,02 & 0,22 & 0,04 & 0,07 & 0,13 & 0,09 & 0,02 & 0,11 & 0,22 & 1 \\
\hline
\end{tabular}

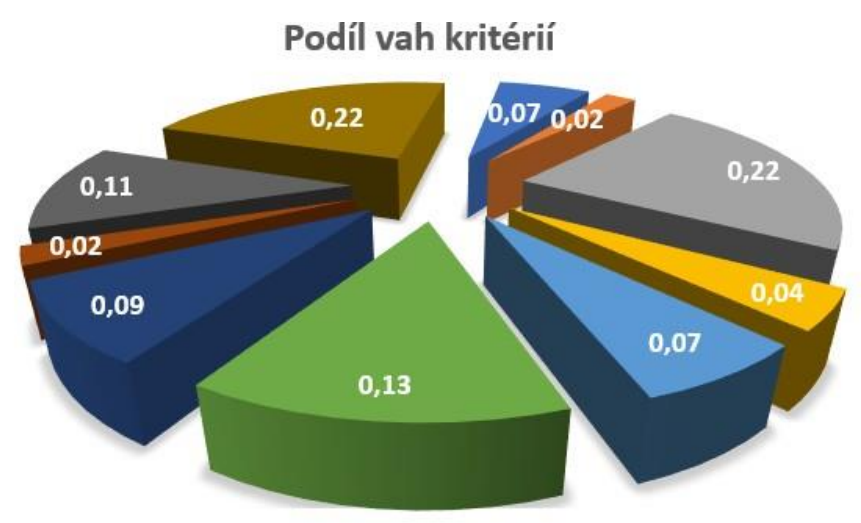

MTOW
Kapacita paliva
Dolet

Cestovní rychlost
Spotřeba paliva
Dostup

- Kapacita pasažérů

- Spotřeba paliva na sedadlo

- Payload

Obr. 1: Stanovení vah 
Dalším krokem je použití některých z metod stanovení hodnoty variant, velmi často používaná je například Metoda přímého stanovení dílčích ohodnocení, která využívá zpravidla desetibodové stupnice, přičemž 1 bod odpovídá nejhoršímu hodnocení a 10 bodů nejlepším hodnotám kritérií. Dílčí ohodnocení variant vzhledem k jednotlivým kritériím určuje přímo hodnotitel, respektive letecká společnost, provozovatel, nebo např́iklad skupina rozhodovatelů. (Fiala et al., 1994)

Tab. 5: Stanovení hodnoty variant

\begin{tabular}{|c|c|c|c|c|c|}
\hline \multicolumn{2}{|l|}{ Kritérium } & \multirow{2}{*}{$\begin{array}{l}A 220 \\
-100 \\
\end{array}$} & \multirow{2}{*}{$\begin{array}{l}A 220 \\
-300 \\
\end{array}$} & \multirow{2}{*}{$\begin{array}{c}\text { B737 } \\
\text { MAX } 7\end{array}$} & \multirow{2}{*}{$\begin{array}{c}\text { B737 } \\
\text { MAX } 8\end{array}$} \\
\hline Název & Váhy & & & & \\
\hline MTOW & 0,07 & 4 & 5 & 6 & 8 \\
\hline Cestovní rychlost & 0,02 & 6 & 6 & 7 & 7 \\
\hline Kapacita pasažérů & 0,22 & 5 & 7 & 8 & 10 \\
\hline Kapacita paliva & 0,04 & 5 & 5 & 7 & 6 \\
\hline Spotřeba paliva & 0,07 & 10 & 5 & 2 & 1 \\
\hline Spotřeba paliva na sedadlo & 0,13 & 6 & 6 & 6 & 8 \\
\hline Dolet & 0,09 & 6 & 6 & 8 & 7 \\
\hline Dostup & 0,02 & 8 & 8 & 5 & 5 \\
\hline Payload & 0,11 & 5 & 7 & 8 & 8 \\
\hline Pořizovací cena & 0,22 & 6 & 4 & 2 & 1 \\
\hline \multicolumn{2}{|l|}{ Celkové ohodnocení } & 5,80 & 5,76 & 5,73 & 6,16 \\
\hline \multicolumn{2}{|l|}{ Pořadí variant } & 2 & 3 & 4 & 1 \\
\hline
\end{tabular}

V rámci hodnocení Metodou přímého stanovení dílčích ohodnocení lze usoudit, že nejvhodnějším letounem při porovnání vybraných typů letounů je Boeing B737 MAX 8, což je dáno především velkou převahou v kapacitě pasažérů a vysokou maximální povolenou vzletovou hmotností. Jako druhá varianta zde vyšla kapacitně menší varianta Airbus A220 - 100, a na třetí příčce se umístil letoun Airbus A220 - 300.

Po zvážení vybraných realizovatelných variant se letecký dopravce zaměřuje na další, zcela formální a objektivní důvody, mezi které řadíme např́íklad současné složení letadlového parku daného dopravce, stav personálu daného dopravce, např́klad proškolení personálu, a schválení plánu údržby, stejně tak jako dostatečný počet personálu pro servis letounů, kde samozřejmě platí, že pokud se např́klad aerolinie rozhodne pro letoun ze stejné takzvané rodiny, jako příklad můžeme uvést rodinu A220 od výrobce Airbus, tak je možné uplatnit tento plán údržby na všechny provozované letouny z dané rodiny. Ušetří se tím významné množství finančních i personálních zdrojů, tudíž u výrobců, kteří poskytují letouny v rámci takzvaných rodin, které jsou však rozdílné např́klad svou kapacitou, můžeme očekávat, že o tyto letouny bude větší zájem například z důvodu pokrytí širšího spektra poptávky na trhu konkrétním dopravcem.

Dále je brán zřetel na pravidelnost přepravy a obchodní strategii společnosti, případně zda se jedná o nízkonákladového či klasického dopravce. $\mathrm{V}$ dnešní době již tyto dva základní modely splývají v jeden, a jejiž zavedenou praxí, že letečtí dopravci se snaží cílit na mnohem širší spektrum zákazníků, než tomu bývalo dříve. Jako př́́klad můžeme uvést společnost Lufthansa Group, která v rámci holdingu řídí mnoho dceřiných firem jako například Lufthansa Cargo AG, Lufthansa Technik AG, Lufthansa CityLine a další. Případně úspěšné akvizice nízkonákladových leteckých dopravců jako Germanwings, Austrian Airlines apod. 
Strategie soustředit a řídit v rámci holdingu více odvětví letecké dopravy se $\mathrm{v}$ rámci koronakrize ukázala jako správná, a snahu následovat tento trend můžeme pozorovat u dalších leteckých společností.Objem osobní přepravy klesl o více než 80 \% a jedná se tak o největší krizi v letectví od počátků její historie. Letečtí dopravci se tak snaží vymyslet způsoby, jak si s touto krizí poradit, jelikož mají mnohdy zasmluvněnyletouny, na více let dopředu, a zároveň také předplacené letové plány. Mnoho dopravců se s př́íchodem krize snažilo zbavit těchto závazků a ve velkém rozprodávali svoje flotily, př́ípadně je takzvaně zmrazili, a alespoň částečně tak snížili provozní náklady.

Dopravcům, kterým se to nepodařilo, našli cestu např́klad v modifikaci svých osobních letounů na letouny dopravní. První stupeň transformace představovalo zakrytí sedadel, a nakládání lehčích druhů zboží přímo na sedadla, tento zpơsob byl obzvláště často využíván především v první vlně koronakrize, kdybylo třeba rychle přepravit větší množství chirurgického materiálu. Ovšem objemy přepravovaného zboží tohoto charakteru zdaleka nemohly pokrýt nabídku leteckých dopravců. Tudíž přišel druhý stupeň transformace, kdy byly letouny odstrojeny, ve smyslu demontáže sedadel a vnitřního vybavení, které dřívsloužilo k zajištění přepravy osob. A zásilky byly nakládány do lépe přístupné kabiny, s rovnou ložnou plochou a relativně vysokou nosností. Zde je nutné podotknout, že zdaleka nejdůležitější parametr podlahyletounu je její nosnost přepočtená na metr čtvereční. Tato nosnost je samozřejmě na různých částech ložné plochy rozdílná a letečtí dopravci museli vynaložit mnoho úsilí, aby byli schopni zaručit bezpečnost přepravy tímhle typem modifikace letounu.

Poslední fází transformace bylo razantní upravení osobních letounů, tyto úpravy zahrnovaly zastínění a vyplnění oken pro cestující, demontáž palubních odkládacích prostor, upravení nakládacích ploch tak, aby bylo možné náklad ukotvit, a případně další přídavná zabezpečení, která se podílela na zamezení pohybu nákladu v průběhu přepravy. Letouny byly následně přelakovány a často nesly logo nákladní společnosti, která s aerolinií narychlo uzavřela dohodu. V době první vlny se tato řešení mohla zdát jako zoufalá, jelikož modifikace sebou samozřejmě nesly jistou náročnost na personální i finanční zdroje, a nebyly zdaleka ekonomické, nicméně byla to často jediná východiska, jelikož přinášela alespoň částečnou finanční pomoc pro mnohdy zadlužené letecké dopravce, kteří již do této koronakrize vstupovali se zápornými čísly. Později se tato řešení ukázala i jako velmi strategická. (Novák et al., 2020)

\section{VLIV COVID-19 NA PRODEJE LETOUNŮ}

V průběhu roku 2019 byla letecká doprava velmi často využívaní, mnohé publikace uvádějí že počet cestujících leteckou dopravou se každých 15 let dvojnásobně zvyšoval a stejný trend se očekával i pro nadcházející léta.

Avšak nyní jsou předpovědi velmi pesimistické a v následujících minimálně dvou letech jsou očekávány dramatické ztráty. Úřady a ministerstva jednotlivých států byly nuceny vydat zákazy a uzavřít hranice, cožbylo samozřejmě pro leteckou dopravu fatální. Cestovní ruch se v březnu roku 2020 prakticky zastavil. Zavřely se hlavní dopravní tepny a s nimi samozřejmě kaskádovitým efektem poklesl počet pracovních míst, velká část společností at’ už přímo zabývající se leteckou přepravou, nebo $v$ rámci outsourcingu byly nuceny provést personální a finanční změny. Tyto se pak dále projevily v návazných odvětvích, jako hlavní můžeme uvést stravovací a ubytovací služby. Podstatná část leteckých společností se snažila vyřešit tuto situaci, avšak často bylo jediným východiskem oznámení bankrotu, případně žádost o státní podporu. (MZČR, 2021) 


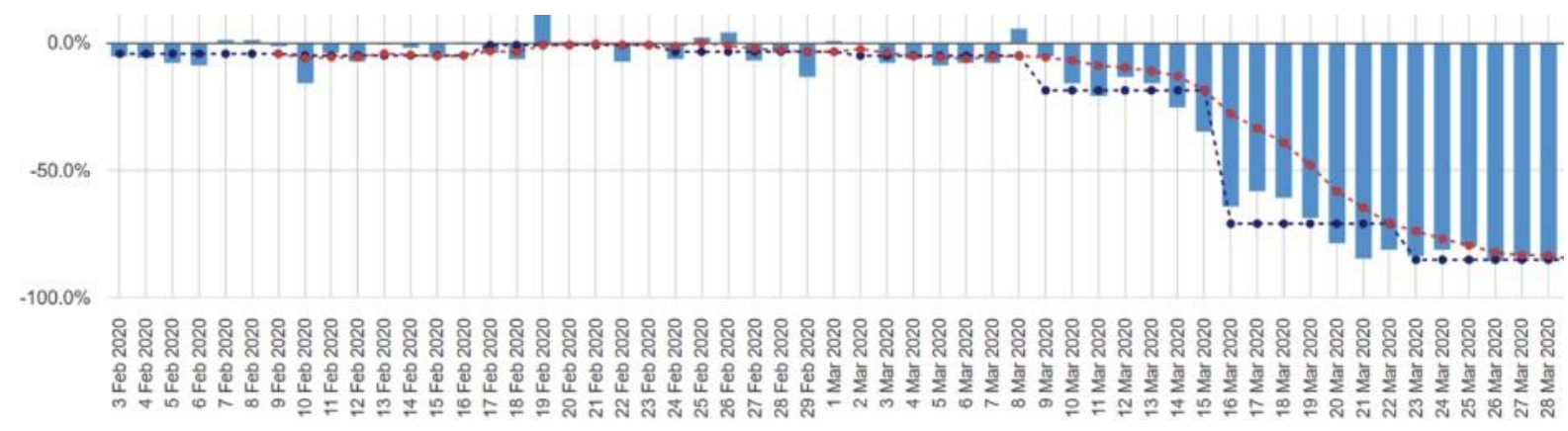

Obr. 2: Pokles provozu vlivem koronakrize v březnu 2020 (Eurocontrol,2021)

Tahle situace samozřejmě výrazně a přímo ovlivňuje prodeje letounů, které za normálních okolností svým charakterem $\mathrm{v}$ návaznosti na stále se zvyšující trend oblíbenosti letecké dopravy mnohonásobně převyšovaly nabídku, a nebylo výjimkou, že letecké společnosti, at' už se jednalo přímo o dopravce, nebo například leasingové společnosti, čekaly několik měsíců až let na dodání poptávaného typu letounu. (Gkiotsalitis et al., 2021)

Tyto prodeje samožrejmě ještě před nástupem koronakrize částečně ovlivnila série pádů, které se konkrétně týkaly výrobce Boeing a jeho letouny řady 737 MAX, jenž jsou doposud uzemněny v důsledku softwarové chyby, nicméně Boeing již podnikl řadu kroků pro opětovnou recertifikaci a navrácení letounůzpět do provozu. (Gkiotsalitis et al., 2021)

Avšak je nutno říci, že Boeing je v globálním měřítku pouze jeden z výrobců a nelze tento konkrétní problém v žádném př́ípadě slučovat $\mathrm{s}$ koronakrizí. $\mathrm{V}$ každém případě jeho pozice na trhu je momentálně ve značné nevýhodě oproti jiným výrobcům.

Již před vypuknutím koronakrize zažívali někteří nízkonákladoví letečtí dopravci vztažmo k hlavním aeroliniím rozmach, a to $\mathrm{v}$ čele s irským dopravcem Ryanair. Tato letecká společnost se stala největší v Evropě na základě počtu přepravených cestujících a předběhla tradiční letecké společnosti jako Lufthansa,British Airways či Air France. Největší výhodou nízkonákladových aerolinií je, že umí dlouhodobě držet náklady na co nejnižších hodnotách. A pořizují si letouny z valné většiny u jednoho výrobce, respektivez jedné rodiny, jako př́íklad můžeme uvést 737 MAX od Boeingu, nebo A320 od Airbusu. Dopravci často na velkých objednávkách dostávají množstevní slevy a jedním z hlavních kritérií tak bývá pořizovací cena. Dalšími faktory jsou také zaškolování posádek a servisní úkony, jež jsou společné pro př́buzné typy od stejného výrobce a letecké společnosti tak výrazně ušetří provozní náklady.

Po vypuknutí koronakrize je patrné, že nízkonákladoví dopravci jako Ryanair nebo Wizz Air měly spříchodem letní sezóny nejvyšší počty letů $v$ porovnání s klasickými dopravci. Tudíž se ukázalo, že jejich strategie ve výběru ekonomicky optimální varianty letounů byly správné, a tento trend se dále rozšiřoval imezi ostatní letecké dopravce. Kritéria jako pořizovací cena nebo kapacita pasažérů byly najednou na pomyslném vrcholu žebříčku hodnocených kritérií. V zásadě platí, že čím vyšší je přepravní kapacita, tím vyššíjsou provozní náklady letounu a vzhledem k současné poptávce po letecké dopravě se postupně začalo měnit složení flotil leteckých společností.

Z uvedené závislosti dále vyplývá že pokles letů v období od března do června roku 2020, ovlivnil strategii výběru letounů dle jejich kapacity, přičemž vyšší počet letů zaznamenaly především aerolinie, které provozují kapacitně menší stroje, které nasazují na regionálních tratích, a z dlouhodobého hlediska jsou tak ekonomicky mnohem lépe konkurenceschopné. Klasičtí dopravci jsou pod mnohem vyšším tlakem, jelikož cílí především na nákladné dálkové lety, které jsou $\mathrm{v}$ současné době mnohem méně poptávány a také čelí omezením jednotlivých států. 


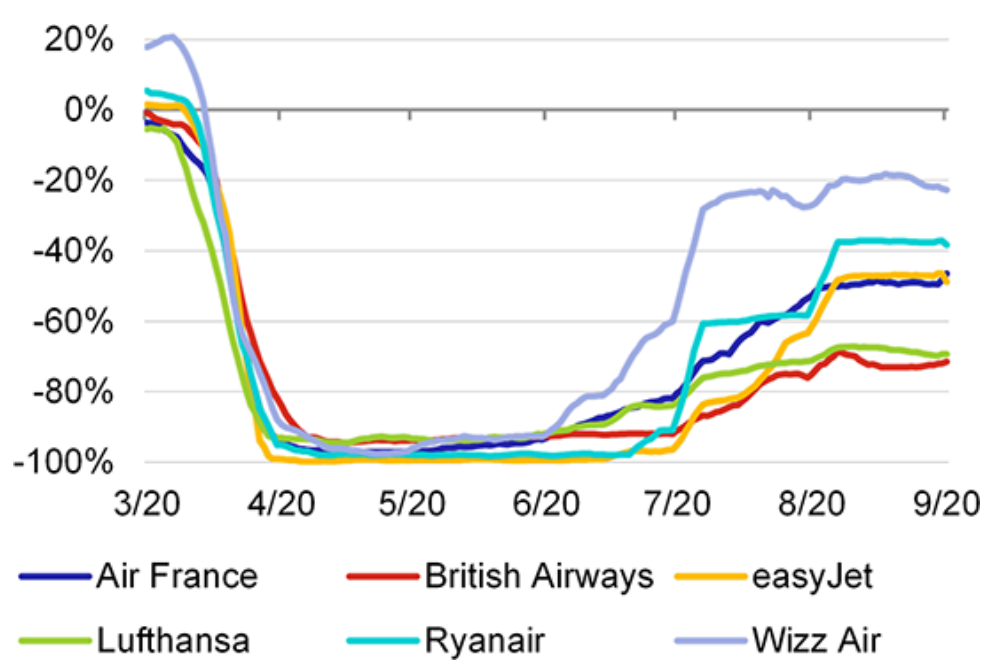

Obr. 3: Denní počet letů v porovnání s rokem 2019 (týdenní klouzavé průměry v \%)

(ČNB, 2021)

Rivalita největších výrobců letadel Airbus a Boeing neustávala ani v době pandemické krize. Propad letecké dopravy zasáhl oba světové výrobce letadel a uplynulý rok pro ně znamenal velkou ztrátu. $\mathrm{Z}$ důvodu velkých počtů objednávek se výrobci připravovali na zrychlení výroby, ale s příchodem pandemie byli nuceni výrobu naopak snížit. Především se jednalo o větší letadla s širším trupem a čtyřmotorové letounys velkými kapacitami.

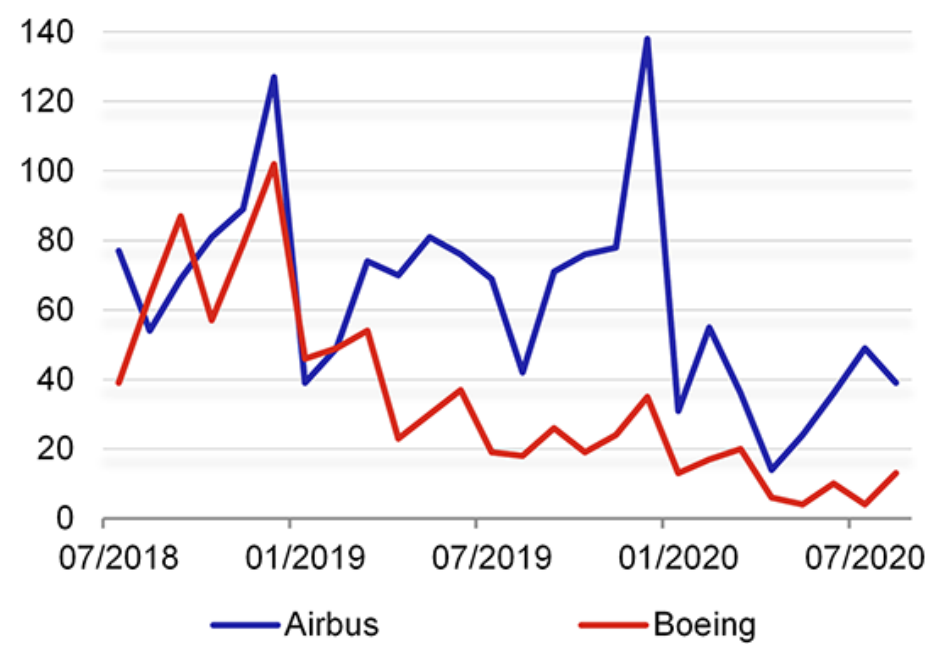

Obr. 4: Dodávky komerčních letadel v kusech (ČNB, 2021)

V rámci porovnání obou výrobců je patrná velká převaha Airbusu, což je však zapříčiněno softwarovými problémy na letounech Boeing řady 737 MAX, jenž vedlo k uzemnění těchto typů letounů. Nicméně Boeing již podnikl kroky k opětovné recertifikaci a v současné době jsou již letouny řady 737 MAXplně v provozu.

Z uvedené závislosti počtu dodaných kusů v rámci let 2018 až 2020 je patrné, že v období vypuknutí pandemie v březnu roku 2020 se letečtí dopravci, respektive provozovatelé výrazně více orientovali na pořizovací cenu, respektive související náklady a přisuzovali jim ještě větší váhu, než tomu bylo $\mathrm{v}$ minulosti. Samotný proces výběru optimální varianty letounu v čase koronakrize byl tak významně ovlivněn a dopravci, kteří chtěli být na trhu konkurenceschopní, museli přizpůsobit své rozhodovací strategie tomuto trendu. 
V případě uplatnění některých z metod vícekriteriální analýzy za současných okolností, lze očekávat výrazný vliv způsobený koronakrizí, na strategie leteckých dopravců a tím pádem i na samotný výběr leteckého parku. $\mathrm{V}$ podstatě lze očekávat, že již při stanovení vah jednotlivých kritérií bude $\mathrm{v}$ rámci objektivního hodnocení přisuzována větší váha kritériím, jenž mají přímý vliv na ekonomickou udržitelnost provozovaného typu letounu. Dle predikcí se letečtí dopravci budou zajímat zejména o pořizovací cenu a kapacitu letounů. Tyto parametry lze očekávat na pomyslném vrcholu stanovení vah kritérií a jejich podoba bymohla vypadat následovně.

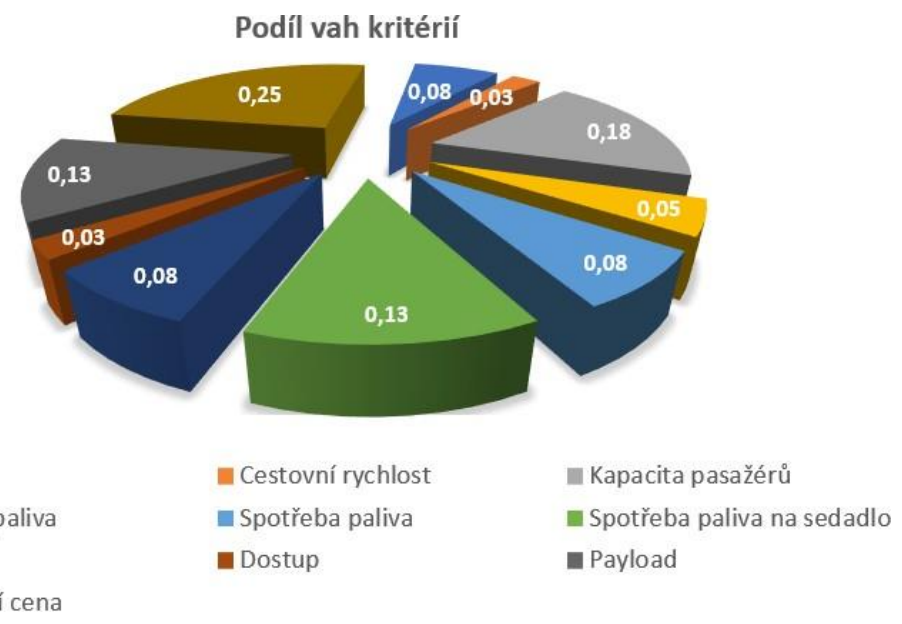

Obr. 5: Očekávaný podíl vah kritérií po zohlednění vlivu Covid-19

Z uvedené závislosti podílu vah kritérií je zřejmé, že kritériím, která přímo ovlivňují ekonomickou udržitelnost vybíraného typu letounu, je přisuzována mnohem větší váha, než tomu bylo před příchodem koronakrize. Samozřejmě velmi důležitý faktorem je stále současná struktura leteckého dopravce, přičemžnízkonákladoví dopravci, kteří poskytují regionální spojení úzkotrupými letouny s menší kapacitou, budou mít při aktualizaci svých letadlových parkủ mnohem menší náklady než klasičtí dopravci. Ti se svými flotilami velkých dopravních letounů jako Airbus A380 či Boeing 747 budou muset restrukturalizovat složení svých parků, a samozřejmě také přeškolit posádky na menší typy letounů, s čímž souvisí další typyorganizačních a provozních nákladů.

\section{POŘIZOVACÍ CENA LETOUNU}

Je zřejmé, že v současnosti nejdůležitějším tématem v souvislosti s výběrem ekonomicky optimální varianty letounu je především pořizovací cena. Momentálně je to již skoro rok, co došlo $\mathrm{k}$ razantnímu poklesu provozu, a to především v sektoru osobní letecké dopravy.

Ačkoliv letecké společnosti si jen zř́́dkakdy pořizují letouny do svého vlastnictví, je pro ně cena letounůvelmi důležitá a její role se vlivem současné koronakrize ještě více dostala do popředí. Od pořizovací ceny se odvíjí i cena leasingu, případně pronájmu od jiných leteckých dopravců, či leasingových společností.

Pořizovací cena se může lišit v závislosti na konfiguraci letounu, jeho vybavení a příplatkových službách. S cenou letounu samozřejmě souvisí také jeho budoucí provoz a údržba, které mohou vykonávatpouze posádky, technici a pracovníci pozemního odbavení letadla s patřičnou kvalifikací. Pokud má letecká společnost více letounů stejného typu, výrazně se sníží náklady na školení personálu. Zároveň jí stačí vlastnit pouze jeden program údržby, který se vztahuje na všechny tyto letouny a zajišt'uje jejich technickou způsobilost k letu, čímž se značně sníží celkové provozní náklady. Vyvstává zde tudíž jedna z motivací aerolinií pro rozšiřování leteckého parku podobnými typy letounů, které již provozuje. 
V případě, že by se letecká společnost rozhodla pro jiný typ letounu, než který již provozuje, musela by si koupit také nový program údržby, případně by musela investovat do dalších modifikací, souvisejících například s parkováním letounů, nebo jejich pozemním odbavením. Což se samozřejmě projeví na provozních nákladech společnosti.

Avšak nelze říci, že provozování stejných typů letounů je vždy méně nákladné než provozování několika různých typů $s$ různými posádkami, programy údržby atd. Je to především z důvodu naplnění kapacit daného letounu, pokud chce aerolinie zavést novou linku, jejíž poptávka nezajistí naplnění kapacit stávajících letounů nebo ji naopak přesáhne, je pro aerolinii mnohdy výhodnější pořídit nový typ letounu,který bude splňovat požadavky pro danou linku.

V rámci konkurenčního boje se výrobci snaží nabídnout co nejnižší ceny a oslovit tak široké spektrum potenciálních zákazníků. Ceny jednotlivých letounů, které jsou pravidelně zveřejňovány, jsou však pro většinu leteckých společností pouze orientační, poněvadž mnohdy zaplatí výrazně méně oproti zveřejněným cenám. Je to zapříčiněno především snahou o zvýšení produkce, př́ípadně zvýšení podílu na trhu konkrétních výrobců. (Evropský parlament, 2021)

\section{ZÁVĚR}

Současná krize má nepochybně nejhorší následky za posledních sto let v historii letectví. Negativně ovlivnila spoustu odvětví letecké dopravy a v horizontu jednoho až dvou let tomu tak jistě ještě bude.

Hlavním cílem př́spěvku bylo představit vhodnou metodiku výběru ekonomicky optimální varianty pořízení letounu, která sestává z mnoha kritérií, jenž musí letecký dopravce zhodnotit. Pro tento účel byla použita jedna z metod multikriteriální analýzy, která objasnila princip samotného výběru. $\mathrm{V}$ další části byl popsán a graficky znázorněn vliv Covid-19, který v březnu loňského roku velmi významně ovlivnil celý světletectví. S ním samozřejmě také priority leteckých dopravců, respektive váhy kritérií, které přicházejí při výběru letounu do úvahy. Jinými slovy, v publikaci bylo znázorněno, jak se změnily tyto priority, a co všechno byli nuceni letečtí dopravci a provozovatelé udělat pro to, aby byli i nadále na trhu konkurenceschopní.

Dále chtěl autor poukázat na to, že nejen samotné prodeje, ale i koncoví uživatelé jsou velkou měrou ovlivněni, a pokles prodejů, př́ípadně zadaných objednávek značně klesl oproti situaci, která tu byla před prŕíchodem koronakrize $\mathrm{v}$ březnu roku 2020. V rámci zachování optimismu můžeme doufat, že přijde $\mathrm{v}$ brzké době zlepšení, ale predikce a trendy tomu v současné době bohužel nenapovídají. Spousta leteckých společností byla v důsledku této krize nucena zabývat se otázkou existence, některé byly nucenyrestrukturalizovat své provozní i fixní náklady, některé přemýšlely o změně obchodní činnosti, avšak pro velkou většinou z nich to znamenalo především personální změny, jelikož zaměstnanci jsou ve společnostivždy ta nejdražší položka a právě proto muselo a ještě pravděpodobně bude docházet k propouštění, mimo jiné z řad zasloužilých pilotů, kteří svou prací přinášeli firmě nemalé tržby. 


\section{LITERATURA}

Fotr, Jiří, Švecová, Lenka a kol. Manažerské rozhodování: postupy, metody a nástroje. Ekopress. Praha. 2010. 474 s. ISBN 978-80-86929-59-0.

Fiala, Petr, Josef Jablonský a Miroslav Maňas. Vícekriteriální rozhodování. Praha: VŠE, 1994. 316 s. ISBN 80-7079-748-7.

Letecká doprava: tržní pravidla. Evropský parlament 2021. [online]. [cit. 2021-07-15]. Dostupné z: https://www.europarl.europa.eu/factsheets/cs/sheet/131/letecka-dopravatrzni-pravidla\#

Koronavirus. Ministerstvo zdravotnictví České republiky 2021. [online] Praha: Ministerstvo zdravotnictví České republiky, 2021[quot. 2021-07-23]. Dostupné z: https://koronavirus.mzcr.cz/

Boj pandemie COVID-19 vs. letecká doprava 2021. [online] Česká národní banka ČNB Praha [cit. 2021-07-15]. Dostupné z: https://www.cnb.cz/cs/o_cnb/cnblog/Boj-pandemie-COVID19- vs.-letecka-doprava-ma-prozatim-jasneho-viteze-celime-historicke-zmene/

Daily Traffic Variation. 2021. Eurocontrol [online]. [cit. 2021-07-15]. Dostupné z: https://www.eurocontrol.int/Economics/DailyTrafficVariation-States.html

Gkiotsalitis, Konstantinos a Oded Cats. 2021. Public transport planning adaption under the COVID- 19 pandemic crisis: literature review of research needs and directions. Transport Reviews [online]. DEC 20, 1-19 [cit. 2021-07-16]. ISSN 0144-1647. Dostupné z: https://www.tandfonline.com/doi/full/10.1080/01441647.2020.1857886 